\title{
Labour, Ecology and History in a Puerto Rican Plantation Region: "Classic" Rural Proletarians Revisited
}

\section{JUAN A. GIUSTI-CORDERO}

The sugar workers of large-scale capitalist plantations in the Caribbean are familiar figures in social history. As portrayed in Sidney Mintz's landmark research in southern Puerto Rico, ${ }^{1}$ sugar workers are manifest rural proletarians: landless wage labourers exploited by "land-and-factory combines". In Mintz's studies, Puerto Rican sugar workers became the classic case of modern rural proletarians. ${ }^{2}$ Such rural proletarians are the dichotomous opposite of peasants: hence given rural populations are either peasants or rural proletarians.

Other studies, including later work by Mintz, discern Caribbean rural groups that are both rural proletarian and peasant, or neither one. ${ }^{3}$

'Sidney Mintz, "Cañamelar: The Sub-culture of a Rural Sugar Plantation Proletariat", in Julian Steward et al., The People of Puerto Rico (Champaign-Urbana, 1956), pp. 314417; idem, Worker in the Cane. A Puerto Rican Life History (New Haven, 1960).

2 Out of his research on Puerto Rico, Mintz is most directly responsible for the use of the concept in contemporary social science. Richard Adams, "Rural Labour", in J.J. Johnson (ed.), Continuity and Change in Latin America (Stanford, 1964), p. 49. Beyond the Caribbean, Mintz's work on "rural proletarians" became influential in the blossoming field of Latin American studies, in Brazil and the Andean zone. See especially Harry W. Hutchinson, Village and Plantation Labor in Northeast Brazil (Seattle, 1956). Anthropologist Thomas C. Greaves referred to Mintz's work on the rural proletariat as his "pioneering contribution": "The Andean Rural Proletarians", Anthropological Quarterly, XL (1972), p. 66. At the same time, and while it was invoked with some frequency in social science research in the $1960 \mathrm{~s}-1970 \mathrm{~s}$, the concept of rural proletarian was not enthusiastically received - in sharp contrast to "peasant" - and has been something of an ugly duckling in social science (perhaps because of its Marxist ancestry). According to Greaves, research on nural proletarians remained "uneven" and "not the product of a long-term, broadly shared research concem among Andeanists": Greaves: "The Andean Rural Proletarians", p. 66. Curiously, Greaves claimed that only the Andean zone came closest to developing "a significant corpus of ethnography" on rural proletarians: ibid. And yet, accepting the conceptual underpinnings of "peasant" inherently carries, I would argue, acceptance of "rural proletarian". In Mexico, the concept of rural proletariat generated broad discussion in the 1970s, though Mintz's work was not addressed and the concept was referred directly to Marx and Lenin. See, for instance, Luisa Paré, El proletariado agricolo en Mexico: ¿campesinos sin tierra o proletarios rurales? (Mexico, DF, 1977), and for a more historical approach Arturo Warman, "El problema del proletariado agrícola", in Paré (ed.), Polémica sobre las clases sociales en el campo mexicano (Mexico, DF, 1979), pp. 85-96.

${ }^{3}$ Richard Frucht, "A Caribbean Social Type: Neither Peasant nor Proletarian", in Michael Horowitz, Peoples and Cultures of the Caribbean (Garden City, 1971), pp. 190-197; Sidney Mintz, "Petits cultivateurs et prolétaires ruraux aux Caraibes", in Centre Nationale de la Recherche Scientifique (CNRS), Problemes agraires de l'Amérique Latine (Paris, 1967). In research that is especially apposite to Pinones, Michael Taussig found that the Cauca Valley's sugar cane labourers were neither peasants nor "full-fledged wage-earning rural

International Review of Social History 41 (1996), pp. 53-82 
Mintz has also written of a "plantation-peasant relation" that seems closest to the "both" approach." In any case, attempts to recombine these concepts can go no further than their own deeply dichotomous structure. "Peasant" and "rural proletarian" first enrich, then constrain our vision. We need to move beyond, towards an elusive history. ${ }^{6}$ The "either"-"neither"-"both" conundrum suggests some of the stark limitations of Western social science.

My research on a Puerto Rican sugar plantation zone in the nineteenth-twentieth centuries, Piñones (Loíza), reveals historical labour patterns and social relations that challenge the "peasant" and "proletarian" categories." The labourers' continuing relation to cropland and other ecologies, autonomous production activities, labour-gang organization, face-to-face relations among themselves and with foremen, non-cash wage relations, non-union activism and old cultural forms shape patterns that may perhaps be characterized as "peasant-proletarian".

"Peasant-proletarian" is a critical approach open to local particulars; it goes beyond essentialist, dichotomous, mutually exclusive categories,

proletarians"; they were "liminal beings [ ... ] neither what they are, nor what they will become": Taussig, "The Evolution of Rural Wage Labour in the Cauca Valley, Colombia, 1700-1970", in Kenneth Duncan and Ian Rutledge (eds), Land and Labor in Latin America (Cambridge, 1977), p. 423; idem, The Devil and Commodity Fetishism (Chapel Hill, 1980), pp. 92, 103. Elsewhere, Taussig characterized the "outlaws" of the Cauca Valley as "black peasants [who] formed a new social class that stood outside society": Taussig, "Black Religion and Resistance in Colombia: Three Centuries of Social Struggle in the Cauca Valley", Marxist Perspectives, VI (1979), p. 102; emphasis added.

"Sidney Mintz, "The Plantation as a Socio-Cultural Type", in Pan American Union, Plantation Systems of the New World (Washington, DC, 1959), pp. 42-50. Mintz's late approaches suggest a reaffirmation of the earlier dichotomy, if now from the point of view of a "peasant" optic. See his critique of a 1978 paper in which Rodney struck a "rural proletarian" note ironically reminiscent of "Cañamelar": Mintz, "Descrying the Peasantry", Review, VI (1982), pp. 609-625. Mintz did not register Rodney's changed perspective in A History of the Guyanese Working People, 1881-1905 (Baltimore, 1981). In this lucid parting work, Rodney characterized post-emancipation sugar plantation labourers as "a permanent hybrid of peasant and proletarian": ibid., p. 218. This suggests a "both" perspective quite different from the 1978 paper, and movement beyond dichotomies and linear history.

3 Juan A. Giusti-Cordero, "Labour, Ecology and History in a Caribbean Sugar Plantation Region. Piñones (Loiza), Puerto Rico, 1770-1950" (Ph.D., State University of New York-Binghamton, 1994), ch. 2.

-The concept of "plantation" shares fundamental methodological premises with "peasant" and "proletarian" in that its landholding pattern is defined as large-scale and virtually monopolistic in a zone: hence its labourers are deemed to be either slaves or rural proletarians.

"Giusti-Cordero, "Labour, Ecology and History". Of course, discussion on peasants and rural proletarians is charged with cultural and political implications. See Arturo Warman, "Los estudios campesinos: veinte años después", Comercio Exterior, XXXVIII (1988), p. 658. Peasants and proletarians are far more than "economic adaptations": see Mintz, "From Plantations to Peasantries in the Caribbean", in Sidney Mintz and Sally Price (eds), Caribbean Contours (Baltimore, 1985), p. 135. 


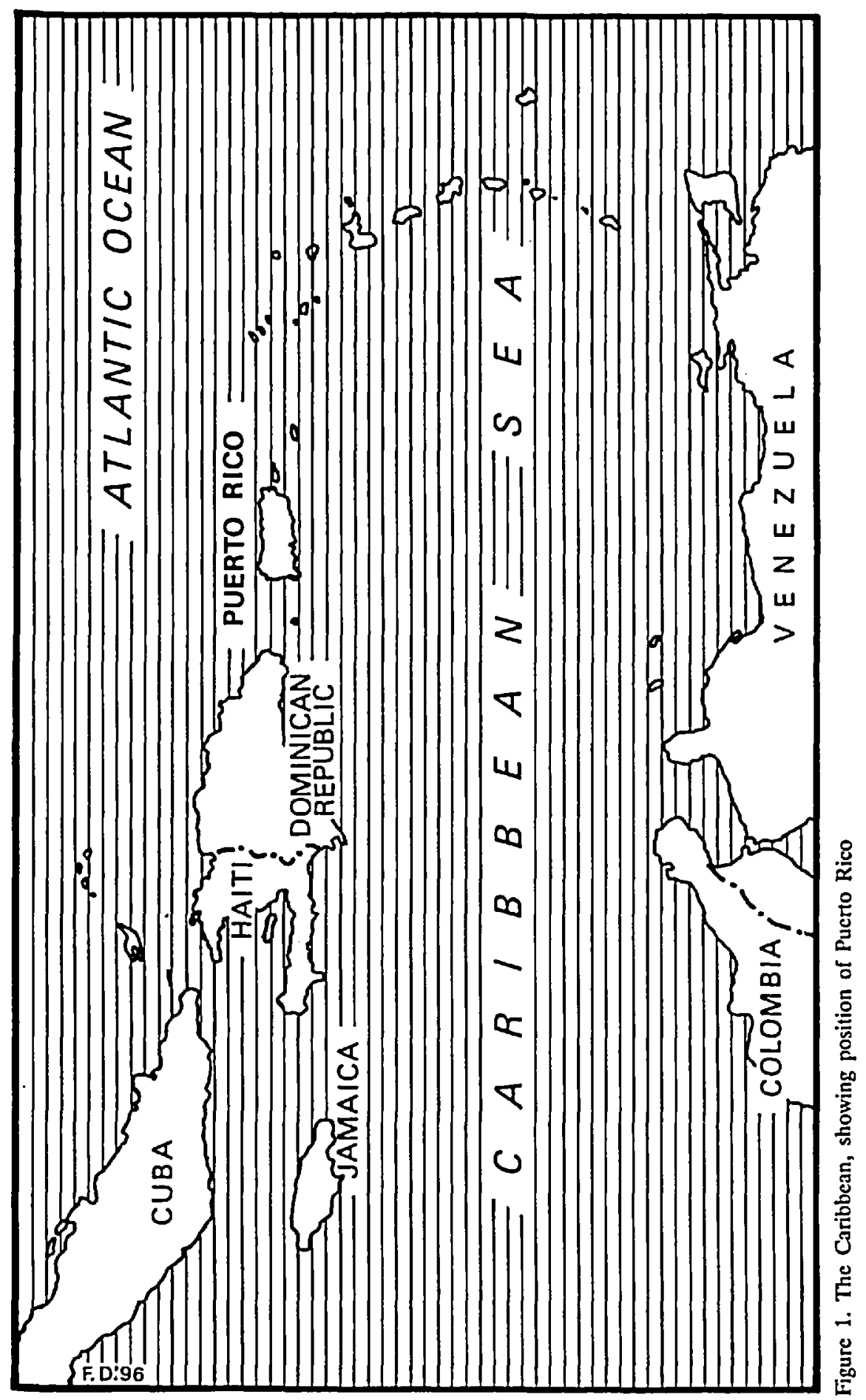




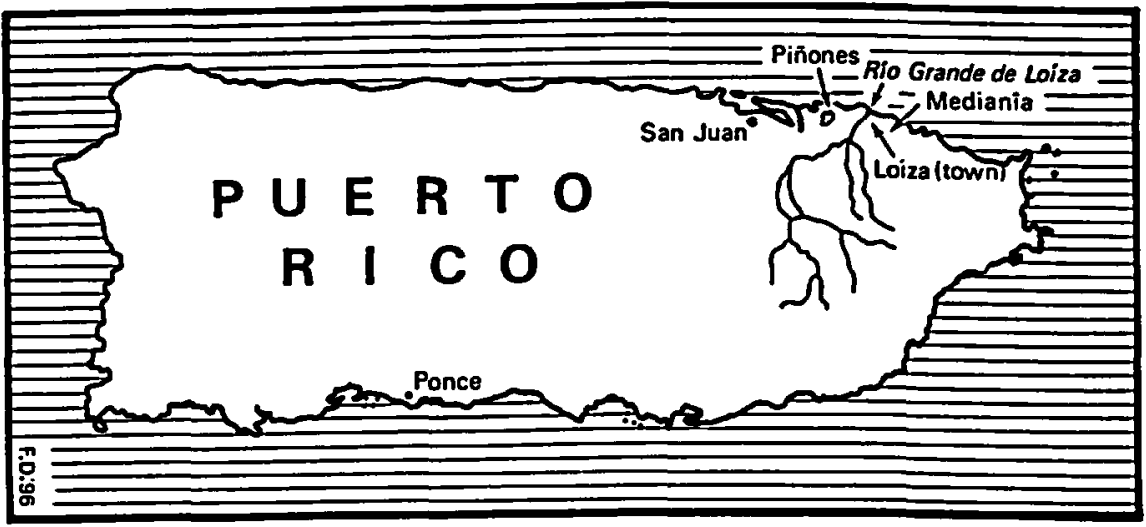

Figure 2. Puerto Rico; the Loízal river basin and littoral

in favour of a conceptually alert and more historical perspective. Through my study of Piñones, I aim to focus on the categories of "peasants" and "rural proletarians" not as social types but as dimensions of social life.

Puerto Rico is an especially significant terrain for a joint re-exploration of these categories, as both "rural proletarian" and "peasant" began their trajectory in contemporary social science in the landmark The People of Puerto Rico project. This project, directed in the late 1940s by Julian Steward, included among its field researchers both Mintz and Eric Wolf. ${ }^{8}$ Mintz and Wolf, who would be lasting collaborators, wrote their dissertations in tandem out of their Puerto Rico research. ${ }^{9}$ At the time, Puerto Rico was an "Inter-American or international pilot object,"10 a "prototype". ${ }^{11}$ Puerto Rico was a showcase for US-promoted development and social change. The island's apparent simplicity and straightforwardness made it especially attractive as a research site for US social scientists. ${ }^{12}$ The Steward team were among the few to realize the island's complexity, if only to establish five component "subcultures"

- Steward et al., The People of Puerio Rico.

'Mintz, "Cañamelar: the Culture of a Rural Puerto Rican Proletariat" (Ph.D., Columbia University, 1951); Wolf, "Culture Change and Culture Stability in a Puerto Rican Coffee Growing Community" (Ph.D, Columbia University, 1951).

${ }^{10}$ Antonio Lauria-Perricelli, "A Study in Historical and Critical Anthropology: the Making of The People of Puerto Rico" (Ph.D., New School for Social Research, 1989), p. 7.

"Richard Weisskoff, Factories and Food Stamps: the Puerto Rico Model of Development (Baltimore, 1985), pp. 85-90. "There is a vast bibliography on Puerto Rico": Gordon Lewis, The Growth of the Modern West Indies (New York, 1968), p. liii. W. Arthur Lewis abstracted his interpretation of, significantly, rural-to-urban proletarianization in Puerto Rico in the widely influential "Economic Development with Unlimited Supplies of Labour", Manchester School (May 1954), pp. 139-151.

12 Michael Lapp, "The Rise and Fall of Puerto Rico as a Social Laboratory, 1940-1965". Social Science History, XIX (1995), pp. 169-199. 
that were themselves depicted in rather oversimplified ways, effectively negating the existence of a Puerto Rican national identity.

The heart of the Steward project, and behind the gamut of six subcultures, was the conceptual dichotomy between peasant and rural proletarian. Mintz researched "rural proletarians" in the island's south coast while Eric Wolf studied "peasants" in the highlands, the two being in frequent consultation between themselves and with other team members. ${ }^{13}$ The other two rural subcultures studied in People of Puerto Rico were variants of the basic peasant or rural proletarian models (one each). ${ }^{4}$ "Peasant" and "rural proletarian" were thus reciprocally constructed as paired opposites in Puerto Rico. People essentially canonized the "either" perspective, but its strategy more fundamentally set down the dichotomous architecture of the whole approach. ${ }^{15}$

In Puerto Rico, more than 100,000 sugar cane field labourers formed the largest occupational group in the early twentieth century, and between a third and a half of the agricultural labour force in then-rural Puerto Rico. ${ }^{16}$ By the early 1940s, the Puerto Rican sugar industry was

4 "San José: Subcultures of a "Traditional' Coffee Municipality", in Steward et al., The People of Puerto Rico, pp. 171-264. The root of the "peasant" concept in contemporary social science is said to lie in the important 1955 paper by Wolf, "Types of Latin American Peasantry: a Preliminary Discussion", American Anthropologist, LVII (1955), pp. 452471. Sydel Silverman, "The Peasant Concept in Anthropology", Joumal of Peasant Studies, VII (1980), pp. 54, 63. In his 1955 paper, Wolf defined peasants as agricultural producers who control their land and who produce for subsistence, a conception fairly close to that of the jibaro. Wolf authored this paper not long after he wrote up his research in Puerto Rico, and while he remained working with Steward at Illinois. On the process beneath and around The People of Puerto Rico, see Lauria-Perricelli, "A Study in Historical and Critical Anthropology". In Wolf's best-known characterization of peasants, to be sure, the focus is on social and political subordination, through appropriation of surplus product, and at least latent social antagonism: Wolf, Peasanis (Englewood Cliffs, 1966). Yet the dichotomous construction of peasant and rural proletarian - perhaps the decisive aspect of the pair - is evident.

${ }^{14}$ The "peasant" variant was Robert Manners's study of Barranquitas, "Tabara: Subcultures of a Tobacco and Mixed Crops Municipality", in ibid., pp. 93-170; the rural proletarian variant was Elena Padilla's study of Barceloneta, "Nocorá: the Subculture of Workers on a Government Owned Sugar Plantation", in ibid., pp. 265-313.

is As Mintz implied, the peasant-proletarian dichotomy was the linchpin of a whole array of dichotomous pairings: "By and large, the difference between peasantry and proletariat was the difference between highland and lowland, between small and large, between other crops and sugar cane, and - some would argue - between white and black": Mintz, "Foreword" to Ramiro Guerra y Sánchez, Sugar and Society in the Caribbean (New Haven, 1964), p. xxxix. On the dichotomizing strategies of the People of Puerto Rico project, and their implications, see Lauria-Perricelli, "A Study in Historical and Critical Anthropology".

${ }^{16}$ Estimates of the Puerto Rico field labour force vary widely. In 1936, the Puerto Rico Reconstruction Administration arrived at a figure of 92,398, see Puerto Rico Reconstruction Administration, Special Census (1936). Mill workers were estimated at 8,482. Others offered a significantly higher figure for field labourers: 113,161 , with mill workers estimated at 10,485: Arthur Gayer, Paul T. Homan and Earle K. James, The Sugar Economy of 
believed to employ in season as many as 165,000 field labourers - more than half the agricultural labour force, and a quarter of the total Puerto Rican labour force. ${ }^{17}$

Much of the true significance of Puerto Rico as a research site at the time was lost on US researchers: Puerto Rico was the most intensely large-scale sugar producing territory in the Caribbean (if not the world) in the twentieth century, the modern "Sugar Island" par excellence. Cuba's production was much larger than Puerto Rico, but not in proportion to its size. And Puerto Rico's evolution, despite (or because?) of its colonial condition, was more "self-contained" than elsewhere: in this century, the densely-populated island was the only Caribbean sugar producer without large labour migrations from elsewhere in the region; nor were there major flows of working-class emigrants from Puerto Rico until the 1940s.

Puerto Rican political traditions and images of cultural identity thicken the significance of the "peasant"-"rural proletarian" dichotomy. Expropriation of the most important sugar latifundia in the 1930s-1940s is a major historical icon of political discourse in Puerto Rico, the threshold of economic and political modernization. Agrarian reform was championed by the social-democratic Popular Democratic Party (PPD) in concert with leading Washington New Dealers, and has been variously linked to mass support by "peasants" (jibaros)" or "proletarians" (obreros cañeros)..$^{19}$ The supposedly white, highland, subsistenceproducing jibaro became the PPD's and the island's leading symbol of cultural identity; ${ }^{20}$ the supposedly darker-skinned, coastal, waged rural proletarian did not. ${ }^{21}$ Marxist-nationalist currents in Puerto Rico's "New History" have but reversed things, and have enthroned the rural proletariat - supposedly betrayed in the 1940s by PPD reformism - as the bearer of the "nation". ${ }^{2}$ Little thought has gone into the possibility that

Pueroo Rico (New York, 1938), p. 162. In Mexico, Sara Lara found it difficult to separate the rural proletarians statistically - as conceptually - from smallholders: "[T] he principal problem lies in the interpretation of the data, above all in the determination of the agricultural proletariat": Lara, "La importancia de la comunidad campesina y las formas de conciencia social de los jornaleros de Atencingo", in Luisa Paré and Ricardo Avila (eds), Ensayos sobre el problema cariero (Mexico, DF, 1979), p. 135.

"Puerto Rico Minimum Wage Board, La industria de azucar de caña en Puerto Rico (San Juan, 1942), p. 18.

1s The PPD's "agrarian radicalism [ . . ] had won the PPD the votes of the jbaros": Raymond Carr, Puerto Rico: A Colonial Experiment (New York, 1985), p. 67.

"Mintz, "Cañamelar". pp. 397-399; idem, Worker in the Cane, pp. 193-203.

20 "The emblem of the [PPD] became the jibaros' straw hat, the pava. To the PPD, the jibaro, the subsistence farmer of the inland regions who was a loyal PPD voter, became the symbol of Puerto Rican identity": Carr, Puerto Rico, p. 115.

21 Juan Giusti-Cordero, "Puerto Rico entre los pueblos antillanos y latinoamericanos. Algunos problemas de método", Plural, IV (1985), pp. 177-195.

2 Angel Quintero Rivera and Gervasio Garcia, Desafio y solidaridad. Breve historia del movimentịo obrero puertorriqueño (Rio Piedras, 1982); Taller de Formación Política, La 
these dichotomies are vastly overdrawn, or indeed that both groups were often the same people. Decades after the US anthropologists left the Puerto Rican "laboratory", ${ }^{23}$ and years after rural social relations became (perhaps mercifully) less fashionable in world social science, the historical character of the sugar cane labour force continues to be a fundamental issue of Puerto Rican history, and one to which we continue to bring new questions.

\section{Piñones: ecology and history, sixteenth-nineteenth centuries}

Piñones, in the municipality of Loíza just east of San Juan, stretches over a 16-kilometre littoral of mangrove forest and lagoons, between the Atlantic Ocean and one of Puerto Rico's main sugar plains. Piñones has a secular history of black peasant-woodsmen-fishermen, going back to sixteenth-century maroons and free blacks. ${ }^{24}$ Sugar centrals had been established near Piñones since the $1880 \mathrm{~s}$, and the piñoneros became deeply involved in sugar cane field labour in the twentieth century. However, Piñones gives no evidence of sweeping proletarianization. Rather, sugar plantation wage labour joined an already complex "peasant" array.

The ecology of Piñones is as heterogeneous, and as coherent, as its inhabitants' historical labour patterns. Piñones (40 square kilometres) compresses mangrove forest, coconut groves, lagoons and cropland at the point where the Loíza coastal plain meets the Atlantic Ocean. Piñones' coastline stretches from Puerto Rico's largest lagoon system to its largest river. The Luquillo mountain chain, only 10 kilometres away, catches moist trade winds and promotes rainfall; the Loíza plain is the wettest in the island.

Piñones' population in 1910 was 721 , in 1920 it was 779, and 1,035 in $1936 .{ }^{25}$ Earlier demographic information is meagre. The villages of Piñones stand on a 1,400-acre narrow and irregular "barrier island" between the forest and the surf, as narrow as 400 metres at some points and formed mostly of fertile sandy loams and alluvial soils. The Piñones mangrove forest is the largest coastal forest in Puerto Rico. ${ }^{26}$ Until the

cuestion nacional: el Partido Nacionalista y el movimiento obrero puertorriqueño (Río Piedras, 1982).

23 See Lapp, "The Rise and Fall of Puerto Rico as a Social Laboratory", pp. 169-199.

24 Jalil Sued Badillo and Angel López Cantos, Puerto Rico Negro (Ŕ́o Piedras, 1986), pp. 25-27.

2s US Bureau of the Census, Thirteenth Census (1910), Population, Barrio Torrecilla Baja; Fourteenth Census (1920); Puerto Rico Reconstruction Administration, Special Census. In 1990, Piñones' population was 1,978: US Bureau of the Census, U.S. Population Census (1990).

${ }_{26}$ As much as 70 per cent of the original Piñones-Hoyo Mulas wetlands were drained in the late nineteenth-early twentieth century to form canefields and pastures. 
late nineteenth-early twentieth century, the forest and the associated wetlands (poyales) stretched over 8,000 acres. Piñones' intricate ecology and its aqueous boundaries mirror its social complexity.

Piñones has been inhabited for at least a millenium. The forest afforded firewood, and its lagoons rich fishing; clams and land-crabs abounded. On the fertile Piñones "barrier island", the Taínos grew crops such as manioc, yams and maize. ${ }^{27}$ Black settlement in Piñones probably began shortly after the Spanish conquest in 1508-1511. The prolific wilds of Piñones attracted Taíno and African maroons fleeing enslavement in the mines and haciendas of the Loíza plain;"28 free black settlers and hunters from adjacent Cangrejos and Loiza; and outlaws and fugitives. ${ }^{29}$ The "enlightened" Fray Iñigo Abbad condemned freedmen that lived in forested coastal zones:

without means of subsistence, they settle in huts in the woods [se arranchan] where they live from fishing and theft, or trading contraband in pirogues without cognizance of either judge nor priest to observe their conduct; which prejudices might be avoided if they were given land where they could live from their labour. ${ }^{30}$

Yet they already had land, and much else, on which they lived off their labour. Piñones, like several other zones in Puerto Rico, was an outlaw black Cockaigne: an ecologically rich domain of autonomous peasants, who resisted the appropriation of their land and subordination of their daily life. To the colonial authorities, Piñones was a peasant "utopia" of the sort they did not care for. That Piñones lay along a major contraband route, when contraband was the principal form of overseas commerce in Puerto Rico, may be no coincidence either.

Eastern and western Piñones followed somewhat different trajectories. Eastern Piñones belonged to the Dominican order until 1838. Twenty or so slaves cultivated a small portion of the "Los Frailes" estate. The slaves had a fairly autonomous livelihood, especially as the Dominican order in Puerto Rico withered after 1800 . In western Piñones, a wealthy and powerful creole regidor, Tomás Pizarro, "gradually took over land at his whim from the poor [los pobres]" in the 1790 s and attempted to

27 The earliest Arawak site in Puerto Rico is Hacienda Grande, just across the Rio Grande from Piñones (c. AD 100). In Piñones itself, a preliminary, unpublished survey by the Institute of Puerto Rican Culture established 68 Arawak and pre-Arawak sites in Piñones and 57 additional sites in the cave-rich karst hills $3 \mathrm{~km}$. south: Jaime Vélez, $A$ Study of the Piñones Special Planning Area (San Juan, 1989).

23 Sued Badillo, "El poblamiento etno-histórico del Valle de Loiza entre los siglos XVIXIX", Revista de Historia, II (1986), pp. 24-50.

20 Gilberto Aponte, San Mateo de Cangrejos (comunidad cimarrona en Puerto Rico): notas para su historia (San Juan, 1985), p. 55; Fray Iñigo Abbad y Lasierra, Historia geogrófica, civil y natural de la Isla de San Juan Bautista de Puerto Rico (Rfo Piedras, 1959 [1788]), p. 153.

30 Ibid., p. 154. 
force them into sharecropping. ${ }^{31}$ The piñoneros preferred to move elsewhere in Piñones. This first-known mass eviction in Piñones had, in the long run, little consequence. Despite the claims of Pizarro and later titleholders, the hamlets (caserios) of La Torre, at the west end, and Piñones Adentro, towards the middle, were formed in the late nineteenth century.

In 1838 the Crown seized Los Frailes in eastern Piñones. The colonial government found dozens of black and mulatto families "settled on their own authority" (avecindados de su propia autoridad): ${ }^{32} 44$ households occupied 362 cuerdas, with 124 of these under cultivation, mostly in manioc and maize, and had 208 head of livestock. ${ }^{33}$ The government was unable to evict for another decade. The context was significant: slave revolts in the French islands and a harsher slave code in Puerto Rico in 1848, and in 1849 a new workbook (libreta) system for the island's free population. ${ }^{34}$ This second eviction in Piñones, too, had little permanent effect. The best-documented genealogies of present-day Piñones families begin with the slaves and settlers of Los Frailes in the late eighteenth century.

In both eastern and western Piñones throughout the nineteenth century, the piñoneros continued to live off their fecund cropland, forest, lagoons and coastline, prompting furious denunciations by the colonial authorities as "usurpers", "intruders" and "prowlers". ${ }^{35}$ Piñones was an annoying "backwoods of difficult vigilance" and "a den of acts prejudicial to morality, order and public safety". ${ }^{36}$

Agriculture and livestock, woodcutting and charcoalmaking, and fishing and marine gathering formed a complex "peasant" totality. Cassava was the island's breadstuff before the onset of massive US flour imports in the nineteenth century, and retained a market in San Juan among the lower classes; and charcoal remained the major cooking fuel until the early twentieth century. ${ }^{37}$ The villagers also planted maize, yams,

${ }^{31}$ In the words of an aged piñonero interviewed by the colonial authorities in 1838. Archivo General de Puerto Rico, San Juan [hereafter AGPR]. Obras Públicas, Propiedad Pública, Box 32 [hereafter AGPR, OP, PP]. Antonio Hermoso to the Intendent, 1 September 1841; emphasis supplied.

32 AGPR, OP, PP, Carolina, Boxes 32 and 120.

${ }^{33}$ AGPR, OP, PP, Box 120 . "Relacion general de los habitantes qe residen en la Hacienda que fue de los Frailes Dominicos en Loiza [ . . . ]" (1848). The cuerda, the traditional Puerto Rican agrarian measure, equals 0.97 acres.

${ }^{34}$ See Fernando Picb, Historia general de Puerto Rico (Rio Piedras, 1986), pp. 173-174; Sidney Mintz, Caribbean Transformations (Chicago, 1974), pp. 91-92.

${ }^{3 s}$ AGPR, OP, PP, Box 124, Ló́za 1873-4, File 517, f. 71.

${ }^{36}$ AGPR OP, PP, Box 120, Exp. 1418, t. 78. Tribunal de Hacienda to Superintendent, 19 June 1850.

37 "Charcoal burning involved cutting a large quantity of wood, which was then chopped into smaller pieces, tightly packed, covered with bush and dirt to reduce oxygen, and bumed at a very low heat": Karen Fog Olwig, Cultural Adaptation and Resistance on St. John. Three Centuries of Afro-Caribbean Life (Gainesville, 1985), p. 109. 
rice and melons; they grazed cattle, goats, pigs and sheep; and they gathered coconuts. Fishing in the riverine estuary, and above all in the lagoons, was an integral part of the "peasant" mode of life of the piñoneros.

At the same time, important slave haciendas developed hard by Piñones in the 1820s-1840s, on drained wetlands just south of Piñones Lagoon. Just across the Piñones Lagoon, the 100-slave, 1,000-acre Hacienda Machicote was established in the 1840 s by the Marqués de Machicote, a leading pro-slavery figure. Immediately south and southeast of Machicote, numerous (albeit smaller) slave haciendas dominated the districts of Hoyo Mulas and Canovanas.

The villages and the sugar centrals, 1890-1920

In the $1890 \mathrm{~s}$, the majority of the piñoneros lived in its eastern area, on the Los Frailes sea-shore. Settlement remained titleless and relatively dispersed..$^{38}$ Wealthy sanjuaneros purchased lots of Los Frailes land from the Crown treasury in the $1870 \mathrm{~s}$, but did not meet their payments, insisting that the Crown definitively oust the "prowlers". On two of those lots, a partially mechanized mill was established in 1876. The 400-acre plantation was the object of continuing incursions by "prowlers" (merodeadores) who cut down trees, made charcoal, took sugar cane and rustled cattle. In 1879 its manager lamented: "the damages to the property increase by the day". ${ }^{39}$ The mill closed a year later. In 1890 the newly formed Central Buena Vista, operating out of Hoyo Mulas, purchased large lots in western Piñones, but only to exploit their wood (especially firewood for the mill). Piñoneros began to cut wood for the plantation on a task-work basis. ${ }^{40}$

In 1894, 61 bohios and ranchos (thatch-palm cottages) were recorded in Piñones: of these, the largest number (30) was at La Arena, on the Los Frailes sea-shore; ten more were further south, at Hato Arriba. By 1910 there were almost double the number of households (121) and 721 inhabitants. By 1920, emigration began to have an effect, and Piñones' population increased much more slowly. Within Piñones itself there was also a marked shift west, towards San Juan: La Arena and adjacent

38 Post-emancipation St John, again, was comparable: "[t]he descendants of the slaves made their living from small farming, fishing, and charcoal burning. They lived in their own settlements scattered about in the bush on small plots of land." Olwig, Cultural Adaptation and Resistance, p. 2.

39 Barasoain \& Cia. to the Crown Treasury, 6 February 1879. AGPR, OP, PP, Box 126, Loiza 1879-81, Leg. 35, Exp. 18, ff. 1, 9. Another landowner next to the same Real Hacienda lot denounced "the abuses both of cutting trees and making charcoal". AGPR, OP, PP, Box 126, Exp. 28. Administrador Central de Contribuciones y Rentas a la Intendencia, 13 November 1879.

- AGPR, OP, PP. Box 134, Antolin Romero to the Commander of the Department of Puerto Rjco, 28 March 1900. 
Monte Grande contracted, while Piñones Adentro and La Torre grew. ${ }^{41}$ Through these decades, the piñoneros' activities continued to express a "peasant-like" understanding of their ecology. Not unlike many scholars today, colonial officials in the nineteenth century defined the piñonero "squatters" merely as "landless". However, land tenure and labour patterns lead us to a more complex and historical portrayal. The piñoneros' smallholdings were undoubtedly important, and moreover much of the subsistence was obtained through a fairly spontaneous relationship to the zone's ecology. Woodcutting in the large Piñones forest and fishing in its lagoons shaped a deepened "peasant" (or just "human"?) sense of the Piñones ecology and of the world at large. And Puerto Rico courts have retroactively sanctioned the claim that the Piñones households were not squatters, having acquired legal title to their land through adverse possession at least by the early twentieth century. ${ }^{42}$

By going about their complex, resilient and autonomous ways, the pinoneros defied and defined the boundaries of "normality" in the adjacent capital of San Juan. This history marked both the peasant and the proletarian relations of the piñoneros, and perceptions of these relations by piñoneros and others, well into the twentieth century. It would be expected that the transformation of the piñoneros' "peasant" relations would be neither straightforward nor swift.

Indeed, decades after the US invasion in 1898, large-scale sugar production remained in the periphery of Piñones. In 1908, the Buena Vista holdings were absorbed by the Central Canóvanas, which was based in Canóvanas 6 kilometres away. It was the Central Canóvanas which most profoundly marked Piñones' history in this century. After long development out of a cluster of slave haciendas in barrio Canóvanas, the Central Canovanas (founded 1881) straddled most of the Loíza coastal plain, including Piñones.

Central Canovanas was founded by resident Spanish and US investors, but was soon taken over by a British firm, the Colonial Company, which owned sugar centrals in Guyana and Trinidad. In 1908, just as Central Canóvanas absorbed Buena Vista, Canóvanas was acquired by a Puerto Rican/Spanish corporation that included existing large landholders from the region, a further expression of the vitality of regional social relations. ${ }^{43}$ By 1920, the Central Canóvanas encompassed canefields, large

${ }^{41}$ US Bureau of the Census, Thirteenth Census (1910). Population, Loiza, Barrio Torrecilla Baja; Fourteenth Census (1920).

12 Compañla de Fomento Industrial vs. Antbal Quiñones Bulerin, Civil Núm. 69-4980, Tribunal Superior, Sala de San Juan (1969); PFZ Properties, Inc. vs. Demetria Escalera Osorio et al., Civil Núm. 88-1823, Tribunal Superior, Sala de Carolina (1988).

4 Giusti-Cordero, "Hacia otro 98: el 'grupo español' en Puerto Rico, 1890-1940 (azúcar. banca y política)", Boletín del Centro de Investigaciones Históricas, 9 (1995-1996); idem, "En búsqueda de la nación concreta: 'el grupo español' en la industria azucarera de 
areas of mangrove forest, cocales, pastures and cropland. The development of the Central Canovanas expressed and transformed the region's historical ecology.

In the early twentieth century, Central Canovanas was not among the very largest of sugar centrals in Puerto Rico; it invariably ranked fifth or sixth in importance. But Central Canovanas had perhaps the most intensely "capitalist" canefield infrastructure on the island: the Central's drainage and rail networks were the largest and most complex in Puerto Rico. And as a significant sign in terms of social relations, Central Canóvanas remained in Spanish-creole hands until 1925. In that year, Canóvanas was absorbed by a US sugar corporation, the Fajardo Sugar Co. - the largest landholder in Puerto Rico. The Buena Vista, Loíza and Fajardo sugar central corporations successively owned most of the Pinones communities' cropland, pastures and cocales (some 1,200 acres); much of the Piñones mangrove forest; all the adjoining canefields south of the forest; the haystack hills to the south; but hardly the hundreds of piñoneros themselves.

In this historical context, the pinioneros were transformed from "peasants" into "peasant-proletarians", and perhaps ultimately into "proletarians", but all these moments are complex and contradictory in character, and are linked in hardly linear ways.

The piñoneros turn to the cane: seasons, and seasons within seasons

The earliest record of Piñones workers in the canefields dates from $1881 .{ }^{4}$ From about 1910, most Piñones male adults worked in the fields of the former Machicote slave hacienda during harvest time (zafra). In the milieu of the canefields, the "dead time" (tiempo muerto) saw the labourers digging and cleaning drainage ditches, cane planting, weeding and cutting trees for new canefields. "The zafra tapered off beginning in July, and by September there was almost no work" (144). ${ }^{\text {t5 }}$ From August to November, only the colonia's migrant labourers and agregados (tenant labourers) were hired. Then in November and December there was almost no work in the canefields: that was the heart of the dead time or the "winter" - "the invierno, as we called it" (160).

The passage of these "labour seasons" - "annual convulsions of class

Puerto Rico, 1890-1920", in Consuelo Naranjo et al., La Nación Soriada: Cuba, Puerso Rico y Filipinas anie el 98 (Madrid, 1996), pp. 211-224.

* AGPR, OP, PP, Box 127, "Expediente levantado por Alealde de Loiza y el Comisario de Torrecillas [ . . ]", 19 July 1881, f. 60. Two years later, a Real Hacienda list of squatters on a lot adjoining Virginia included two intrusos "who really and effectively do not possess goods of any kind, living solely from their labour as braceros [agricultural laborers]". Alcalde to Administración, 19 November 1883, f. 166.

"Numbers in brackets refer to page numbers in the author's transcript of taped intervieus. 
relations" ${ }^{46}$ - pervaded the interaction of peasant and rural proletarian labour. This major dimension was not fully present in the "rural proletarians" and "peasants" of The People of Puerto Rico. People defined its "subcultures" in terms of single labour patterns corresponding to a given preponderant time and a single space. Mintz's study of the coastal "subculture" of Santa Isabel/"Cañamelar" left the different, complex spaces and times of the litoral in a penumbra. In Mintz's account, at those times when the sugar labourers were not "proletarian" they were simply formless, living in "dead time":" a time that almost did not exist, a history-less time. Similarly, Wolf's study of the "highland" peasantry disregarded the large seasonal flows of "highland" labourers to work on the coast, on a daily or weekly basis. ${ }^{48}$ Thus Wolf did not contemplate the possibility that a labourer might, at different times of the year, straddle more than one "subculture";"9 or that Puerto Rico's various "subcultures" had profound historical connections. The People researchers did not contemplate that Puerto Rico cane labourers could have been "proletarian" and "peasant" at different times of the year, and in different spaces. In People, and despite suggestive intimations to the contrary, the seasons and time are presented as uniformly "Western": flat, linear and homogeneous, and without a specific history.

While not much more alert to the specificity of rural social times, Marx's distinction between labour time and production time adumbrated

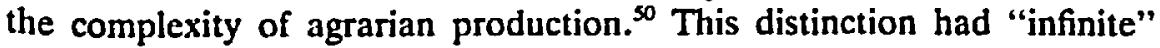
variations across and within branches of production, and importantly contributed to render the analysis of capital more historically concrete. Some of the strongest expressions of this distinction involve natural cycles, as in agriculture where there is a more extended labour time, and a marked difference between labour time and production time. ${ }^{31}$ The perimeter of social relations beyond, though connected with large-scale agriculture, is absent from Marx's enquiry.

* Brian Pollitt, "Some Problems in Enumerating the 'Peasantry' in Pre-Revolutionary Cuba", Journal of Peasant Studies, IV (1977), pp. 167-168.

"For Mlintz's account of "dead time" on the southern coast of Puerto, see Worker in the Cane, p. 22. A mill-centred concept of "dead time" also misconstrues the agrarian crcle of the sugar cane itself. For it is precisely during the "dead time" that cane grows most vigorously and is thus most alive: for the cane, it is the harvest that will mean death.

"Wolf, "San Jose", pp. 230-232.

* Wolf's account of the Ciales agrarian/religious calendar leaps from Three Kings Day to Holy Week, see ibid., p. 200. This period (January-April) is the height of the sugar harvest on the adjacent coast; many cialeños probably migrated even for day-work, especially in the late $1940 \mathrm{~s}$ when motor transport was widespread.

so Marx, Capiral, vol. II (Aexico, DF, 1959), chs 12 and 13; esp. pp. 209, 213-216.

"Ibid., pp. 209, 213. For some implications of production time vs. labour time, see Susan Archer Mann, Agrarion Capiralism in Theory and Practice (Chapel Hill, 1980); César Ayala, "La nueva plantación antillana (1898-1934), Boletín del Centro de Investigaciones Históricas, 8 (1994-1995), pp. 121-165. 
Peasant rhythms defined "dead time" and impinged on the zafra itself. The coastal labourers" "peasant" calendar was actually a peasant/ fisherman/woodsman (and more) calendar, ${ }^{32}$ which meshed with yet other calendars: first, the specific subtropical natural-ecological calendar of Puerto Rico; and second, the religious-festive calendar, which the coastal labourers observed, even if they were not frequent churchgoers; perhaps because it subsumed, as elsewhere, ancient astronomical calendars. ${ }^{53}$

In all, there were not one but at least five interwoven calendars and seasonal turns in the shaping of peasant-proletarian labour patterns in early twentieth-century Puerto Rico. It is in this matrix where we may search for regularities beneath seemingly "irregular" work rhythms. . $^{34}$ The complex array of calendars and seasonal patterns, none of which is clock-like to begin with, generates much of the ambiguity and contradiction - the "practical logic" - that Pierre Bourdieu detected in rural calendars. ${ }^{\text {s5 }}$

A simple opposition between zafra and tiempo muerto assumes exactly what must be proven: that the social relations and attendant temporal rhythms of coastal peasant life had lost all vitality. In fact, the movement from tiempo muerto to zafra, considered generally, condensed within an annual cycle a century of the piñoneros' history. Living in "dead time" resonated with the "peasant" Piñones of the eighteenth-nineteenth centuries. There was dire material poverty in dead time, no doubt, but there was hardly much wealth during the zafra, or in rural social life generally throughout history; and material scarcity should not cloud the significant shift in social relations and historical meaning that the labourers traversed.

n Gervasio Garcia writes of the agricultural labourers" "irregular rhythm", at odds with a "strict labor discipline": Garcia, "Economía y trabajo en el Puerto Rico del siglo XIX", Historia Mexicana, XXXVIII (1989), p. 865. Garcia argues that this "irregularity" was generated by the "intermittent and seasonal labor in the sugar plantations".

${ }_{33}$ In Puerto Rico, the most conspicuous natural seasons are associated with the religious calendar: the dry, warm Lent (Cuaresma) and the cool and rainy Christmas. The former is associated with the best fishing, and occurred in the midst of the sugar cane harvest; and there was alternation between both forms of labour even then. The rainier season at the end of the year made day-long work in the canefields relatively difficult; but the rains hardly forestalled the more intermittent rhythms of peasant production on the sandy, well-drained Piñones cropland, nor fishing in the lagoon. Indeed, rainy spells are excellent for crab-catching.

st On the superimposition of calendars in slave production in nineteenth-century Martinique, see Dale Tomich, Slavery in the Circuit of Sugar. Martinique in the World Economy, 1830-1848 (Baltimore, 1990), pp. 230-233. "The temporal requirements of sugar production coincided imperfectly with the social relations of slavery": ibid., p. 232.

${ }_{\text {ss }}$ Pierre Bourdieu, Le sens pratique (Paris, 1980), pp. 23-26; idem, "The Attitude of the Algerian Peasant Toward Time", in Julian Pitt-Rivers, Mediterranean Countrymen (Paris, 1963), pp. 56-57. Bourdieu cautioned against confusing "logical models", oriented to economy of observation and coherence, with the real principles of the practices: Bourdieu, Le sens pratique, p. 25. "Peasant" and "rural proletarian", of course, are themselves "logical models". 


\section{Peasant and proletarian}

The Central Canóvanas owned or contracted most of the Loiza region's canefields during 1920-1950; the Central's canefields blanketed the coastal plain and climbed hundreds of feet on the foothills just south. In diverse ways - by purchasing higher-yield land, draining poyales, obtaining lower property tax assessments, making exacting contracts with colonos that left the Central almost risk-free, extending the Central's railway system, pushing the Central's supply zone further into the hill country, and so forth - the Central administration steered regional economic activities and social relations to its advantage.

Yet the ecological and social patterns of the Loiza region did not easily yield. Though in straitened conditions, the piñoneros continued to labour in the land and aquatic ecologies of their zone. Their peasant dimensions remained substantial. In the 1910, 1920 and 1936 censuses, a majority of the Piñones male working population did not return cane labour as their primary occupation. ${ }^{56}$ Between 1910 and 1936 the absolute number of cane labourers remained about the same (around 80 ) while their proportion declined with respect to the total number of persons informing occupations: 39 per cent in 1910, 44 per cent in 1920, and 30 per cent in 1936. In 1910, 39 per cent were employed in other agricultural wage labour; 50 per cent were employed in coconut labour in 1920; and in 1936,38 per cent were engaged in charcoalmaking.

Smallholding continued to be significant in Piñones in the early twentieth century, with the same array of crops as in the mid-nineteenth century. The 1910 US Census listed 721 inhabitants living in 121 households, and 43 fincas ("farms"), which corresponds to a third of the households. ${ }^{57}$ Hogs, goats, cattle, and even sheep were common. "Here everyone has had goats and pigs" (36). Piñones agriculture built partially on Arawak and African patterns, growing the same crops as Taínos on the same sandy soils cultivated by the Taínos for centuries. Mounds (montones) were used for cultivating manioc in conucos into the late nineteenth century; ${ }^{38}$ and manioc plantings were always distinguished from the rest of the field (tala). A complex array of highly productive crops was also grown..$^{39}$ In fishing, trasmayos of parallel Arawak, African

so On the perils of census categories identifying "primary occupations", see Brian Pollitt, Agrarian Reform and the "Agricultural Proletariat" in Cuba, 1958-66: Some Notes (Glasgow, 1979), p. 4.

7 US Bureau of the Cerisus, Thirteenth Census (1910); Social and Population Schedules, Loiza, Barrio Torrecilla Baja.

ss Jaime Vélez, Personal Communication (1995). Vélez, an archaeologist, has detected traces of mound formation in the old core of Piñones settlement in La Arena.

59 Francisco Moscoso, Tribu y clases en el Caribe antiguo (San Pedro de Macoris, 1986), pp. 420-428. On Arawak conuco agriculture, see David Watts, The West Indies: Patterns of Development, Culture and Environmental Change Since 1492 (Cambridge, 1986), pp. 53-61. 
and European origin were used, as well as hand-fishing. It is hard to find any labour technique of specifically and uniquely African origin..$^{60}$ However, the deep practical understanding of the coastal ecology, and indeed the very disposition to settle and remain in this not wholly hospitable ecology (given its insect pests and malaria) does suggest African legacies. In any case, the question of cultural origins in the world of labour remains little-studied in Puerto Rico.

The Piñones forest was an important source of firewood, charcoal and madera negra. Madera negra is the aged wood of trees fallen and buried centuries ago in the deep muck of the forest floor. In the midst of the forest penumbra, large trunks had to be painstakingly pulled out; then the labourers had to cut the nearly fossilized, stonelike wood, then take it to the nearest canal on wagons running on portable rail planks furnished by the Central (223). For a single large trunk, the process might take a week. Work on madera negra, while nominally (and perhaps spatially) "peasant" labour, had striking connections with the canefields. The tough, termite-immune madera negra was chiefly in demand by the sugar plantations themselves, for fence-posts and especially railway cross-ties. Its extraction was gruelling, more so than all other canefield tasks, and workers often preferred the open space and sociability of the canefield.

Coconut labour was also an important form of "peasant" labour in Piñones where, again, vital "proletarian" dimensions quickly surface. Piñones was at the centre of a 4,000-acre plus coconut belt that stretched from the Río Espíritu Santo in Río Grande (just east of Loíza) to Toa Baja west of San Juan. Piñones' cocales extended over 1,300 acres. The Loíza coconut belt - a geographer called it the "coconut fringe" or the "coconut-garden zone" - was the largest in Puerto Rico, and centred the island's coconut industry. ${ }^{61}$ While coconut palms were hardly alien to Piñones in the nineteenth century, the large coconut groves of Piñones originated in the late $1890 \mathrm{~s}$. By the $1920 \mathrm{~s}$, fully-grown cocales stretched across Piñones, in land leased to coconut growers. The Piñones villagers were employed in husking the coconuts prior to shipment, on a piecework basis. An arduous pace of $1-2,000$ coconuts a day had to be maintained in order to earn $\$ 1-\$ 2$, jabbing each coconut on to a mangrove spike - a hazardous task.

A complex and seasonally-variable array of occupations existed in Piñones whereby most male adults and some women incorporated seasonal sugar cane labour.

What people did here was to work in the montes, make charcoal, all those things [... ] Here everyone made charcoal, and when there was no charcoal,

${ }^{6}$ See Eugenio Fernández Méndez, "Los corrales de pesca indígenas de Puerto Rico", Revista del Instituto de Cultura Puertoriqueria, IX (1960), pp. 9-13.

61 Margaret Uttley, "Land Utilization in the Canóvanas Sugar District" (Ph.D., University of Chicago, 1937), p. 65. 
firewood, and when there was no firewood the madera, and when there was neither firewood nor madera, they worked in the cane (238).

However, cane labour was not uniformly a last alternative: cane paid relatively well and was a welcome change from the damp and dark work waist-high in the mangrove muck; it also did not require time-consuming trips to the San Juan market to sell charcoal or produce. ${ }^{62}$ Coconut shelling was more autonomous than cane labour, but was strenous and could be dangerous. The question of choice between activities was complex, and often ran in unpredictable directions. Of course, important social constraints existed on these choices: for instance, alternatives such as cultivating substantially more land within Piñones were virtually closed given customary patterns of land tenure there, and strictures against depriving neighbours and kin of land customarily held. ${ }^{63}$

The peasant and the rural proletarian dimensions of the piñoneros were not discrete; peasant and proletarian dimensions were conspicuous throughout. The piñoneros carried out their autonomous peasant activities in spaces they regarded as their own, through labour they paced and whose product they appropriated, working individually or in small groups. Rural proletarian social relations comprised agricultural labour for a wage, under supervision, and in co-ordination with large numbers of other labourers, both those physically present in the canefields and in the distant sugar mill. Strong physical exertion not solely paced by the labourer and repetitive movement were also major characteristics of rural proletarian social relations. Since the tangents between peasant and proletarian relations were so significant, I choose to approach rural proletarian dimensions rather than to identify a "social type" of rural proletarians or distinct rural proletarian "roles".

Peasant labour in Piñones underwent deep transformations after 1900. Village activities and social relations retained autonomy but in the 1930 s were eroded in their market conditions (charcoal burning) or in their ecology (fishing, hunting, crab catching). Piñones' ecology was literally shrinking as adjacent wetlands were further drained, and population growth and falling prices for firewood and charcoal led to the cutting of much of the mangrove forest. Various nominally peasant activities now had accentuated proletarian dimensions, due to the pace and intensity of work that was demanded: chiefly coconut husking and madera negra. This may help explain why the piñoneros often preferred to work in

6. I have not detected among the old piñoneros a suspicion of wage payment, much less a sense that it was demoniacal or charged with mystical power, such as Taussig found in The Devil and Commodity Fetishism. Of course, until the 1940 s they rarely saw a cash wage, as they were paid in scrip redeemable at the Central store or in other nearby stores.

63 See Taussig, "Peasant Economics and the Development of Capitalist Agriculture in the Cauca Valley, Colombia", Latin American Perspectives, V (1978); idem, "Rural Proletarianization". 
the canefields. "Peasant" labour was increasingly becoming difficult, time-consuming, exhausting and "proletarian" [ . . . even as "proletarian" labour was itself shrinking. The peasant dimensions of piñoneros did not remain aloof from broader transformations, and it would be a serious mistake to view their production activities as part of a changeless "tradition".

\section{Peasants in the cane?}

Perhaps most surprisingly, canefield labour was itself markedly "peasantlike" even into the mid-twentieth century. In the canefields near Piñones an array of tasks spanned age-groups and gender in a "peasant" spectrum, from tasks such as taking lunch to the canefields, weeding and fertilizing - where women and children participated ${ }^{64}$ - to the generally male heart of the cane harvest process: cane cutting and loading.

Planting was carried out by brigades whose members were often linked by kinship and residence. Some children and adult labourers carried the seed, others sowed it, and still others did the actual planting. Planters drove the seed (a cutting from a mature stalk) into the ground with special picks. Sometimes whole lengths of cane were planted in furrows and covered with loose earth. ${ }^{65}$ Fertilizing (regar abono) began after the first weeding and replanting. Like the digging and maintenance of drainage ditches, and like planting, this was fully manual labour. Two applications of fertilizer were made. After the first weeding of the cane, some $400 \mathrm{lbs}$ per acre of fertilizer were applied. A second application was made four to six weeks later. The labourers cast the fertilizer on either side while walking down the furrows (sangrias) between banks. ${ }^{66}$ In newly planted Canovanas fields as much as 3-4 tons of crushed lime was applied to correct acidity and improve texture. ${ }^{67}$ Brigades combined different types of cultivation work as they moved from field to field.

In canefield labour, the Piñones labourers consistently avoided the most "proletarian", most individualized and most perilous canefield task: cane cutting. This task is often erroneously equated with the totality of canefield labour. ${ }^{68}$ Cane loading was much preferred. Indeed, loading

64 While boys from Piñones were active in canefield tasks such as fertilizing, it seems that Pinones women rarely worked in the canefields in any capacity; the women's connection to the canefields was cooking lunch and taking it to their spouses. A number of women from nearby Carolina did work regularly in those tasks.

os Gilmore's Puerto Rico Sugar Manual (New Orleans, 1931), p. 98.

66 Uttley, "Land Utilization in the Canovanas Sugar District", p. 97; German Kali Works [F.S. Earle], The Cultivation of Sugar Cane in the West Indies (Havana, 1926), p. 32.

${ }^{67}$ Ibid., p. 33.

6ee, for example, Eric Wolf, Peasant Wars of the Twentieth Century (New York, 1969), p. 257. In their attitude toward canefield labour, the piñoneros resembled Mintz's main 
equalled cane cutting in its strategic location at the heart of the harvest process. Cane loading paid slightly better than cutting, probably because of the skill and speed involved; a day's work could be delayed by the cane tumbling from improperly loaded carts as these moved on rails. Though less dangerous than cane cutting, loading was probably more strenuous: it included the lifting and heaving of $315-\mathrm{lb}$. iron rail planks for the portable rail track. Over this track passed the small wagons to be loaded with cane. No oxcarts were used in the often wet and sluggish fields of the Central Canovanas. "It was harder work than cutting cane; the llenadores had to both fill the wagons and carry the rail planks" (158). And loading, unlike cutting, directly involved teamwork: all loading was done in pairs of two, one loading from each side of a cart.

Of course, the rhythm and pace of work in planting and fertilizing may not have been wholly peasantlike, and one might well argue that this was decisive. But there is a difference in physical rigour between these tasks and cutting and loading cane. Moreover, there are other "peasant" dimensions that are relevant to all phases of canefield labour, including those that seem least peasantlike. We know that field labour was extremely labour-intensive and relied heavily on manual labour, in sharp contrast to the factory phase of production.

On the whole, it appears to me that the manufacturer of sugar in Puerto Rico is in advance of the cultivation. No pains are spared to erect the best machinery and to get the best results from cane delivered to the mills. As a rule, all operations are under the supervision of experts, and modern sugar making has reached a high state of perfection. But the fields have been neglected. ${ }^{69}$

Manuel Moreno Fraginals has concluded that even into the twentieth century cane cultivation remained technologically in the slave epoch. ${ }^{70}$ However, Moreno Fraginals remained silent on the social relations of production - and more specifically of labour - in the post-emancipation canefields. For his part, in his ethnographic view of canefield labour, Mintz focused systematically on the similarities with urban-industrial labour at the expense of affinities that are at least as strong with regard to peasant labour, to the point of dismissing visibly peasant dimensions as conjunctural anomalies.

In fact, peasant social relations traversed various canefield labour processes (especially planting and weeding). These tasks demanded specialized skills and dexterity (as in machete-cutting) that were common

informant Taso Zayas, the "worker in the cane". Zayas cut cane only once during his decades in the cane, and quit by mid-morning: Mintz, Worker in the Cane, p. 202.

US Tarriff Commission, 1926, p. 259; emphasis added.

${ }^{70}$ Manuel Moreno Fraginals, "Plantaciones en el Caribe: Cuba-Puerto Rico-Santo Domingo (1860-1940)"., in idem, La historia como arma (Barcelona, 1983), pp. 56-117. 
among Puerto Rican peasants. Instead of "deskilling", in terms of "peasant" skills canefield labour was more like "superskilling". These skills were a matter of pride for the labourers, especially in the socialized milieu of the canefields and the "animal spirits" that socialized labour stimulated. ${ }^{71}$ Skill pride facilitated a smooth flow of co-operation with a minimum of supervision, and allowed the workers a sense of personal and group identity in the canefields.

Field labour in the cane was invariably organized in labour gangs. The labour gangs were formed in part through village ties of kinship and friendship; continuous face-to-face relations with foremen, as distinct from overseers; and "peasant" work implements that often belonged to the labourers (machetes, hoes, shovels, etc.). The gangs were not supervised directly by the (white) overseer, who spent his days on horseback making the rounds of the plantation, but by an (almost always black) foreman from Piñones or Carolina. Labour gangs thrust us into the vast and little-analysed field of simple co-operation on a quite massive scale (see below). Francisco Scarano has rightly noted that "the daily interaction between workers, foremen, overseers and managers" in Puerto Rican canefields remains quite under-researched. ${ }^{2}$

As an integral part of labour-gang organization, until the 1940s canefield work was paid by the task (ajuste) rather than in time-wages. Thus there was no "true" wage labour. Mintz overstated the case when he wrote of "the emergence of a 'genuine' rural proletariat" in the 1940s. In the labour gangs, delegation of supervision was no unforeseen windfall. The Puerto Rico Labour Bureau concluded in 1913: "The principal objective of [the ajuste] system, it appears, was to avoid the annoyance of watching over the men who contract". ${ }^{74}$ Moreover, in the Loiza littoral as elsewhere task-work was remunerated by non-cash means such as scrip (vales) that nourished debt relations. Cash is a seemingly secondary attribute of the wage-form that, in fact, is surprisingly important in terms of the social relations and social context that it presupposes. ${ }^{75}$

$n$ Walter Rodney wrote that in Guyana field hands took pride "in their proficiency with cutlass, shovel, and fork": A History of the Guyanese Working People, p. 161. See also Mintz, "Cañamelar", p. 357; Juan Martinez Alier, "Tierra o trabajo': notas sobre el campesinado y la reforma agraria, 1959-60", in Juan and Verena Martínez Alier, Cuba: economia y sociedad (Madrid, 1972), p. 174. The phrase "animal spirits" comes from Marx on simple co-operation; see below.

7 Francisco Scarano, "Las huellas esquivas de la memoria: antropología e historia en Taso, trabajador de la caña". Preliminary study to Taso, trabajador de la caña (Río Piedras, 1988), pp. 36, 40, the Spanish translation of Mintz's Worker in the Cane.

ग Sidney Mintz, "Was the Plantation Slave a Proletarian?", Review, II (1978), p. 85.

74 Puerto Rico Labor Bureau, Report (1913), p. 34.

75 Garcia, "Economía y trabajo", pp. 858-859. I appreciate Gervasio Garcia's comments on this score. It is significant, in terms of theories of capitalists' role in capitalist development, that the transformation into cash time-wages was accomplished in Puerto Rico after 1938 only through widespread labour agitation and aggressive interventions by the Puerto 
Both scrip payment and endebtment have a long history in Puerto Rico, in and out of sugar production. ${ }^{76}$ The last major chapter of these forms of payment of labour in Puerto Rico - which have not, however, disappeared $^{\eta}$ - extended into the $1940 \mathrm{~s}$ in the space of the canefields. Also relevant is the pattern of wages paid for each day's labour (though on a weekly basis), which gave the jornaleros (literally, "day-labourers") greater leeway in terms of the days worked per week.

Too often historical research on Puerto Rico's cane labourers has conflated all "wage" labour into time-wages, in a quest for an early, full-scale proletarianization. ${ }^{78}$ It is hard to argue for a "conceptual" rural proletarian status on the basis of labour gangs, task-payment, non-cash wages and endebtment, and where the forms of supervision, sociability and autonomy are still "face to face" within and between the labour gangs. In "Cañamelar", Mintz registered many of these specificities, but missed their historical, customary (and indeed "universal") character. Remarkably, Mintz labelled the old rural patterns, featuring labour recruiters and gang foremen, ${ }^{79}$ as temporary measures initiated by the US sugar corporations. "Until the corporation had worked out its own estimates on labour performance, it left the jobs of recruiting, bossing and arranging pay of workers with labour recruiters." ${ }^{80}$ And in Mintz's account, the social practices of the recruiters became merely "unscrupulous "." $^{81}$

By and large, it is probably true that peasant labour involved greater skills and more accumulated local knowledge than proletarian labour. But in other ways, proletarian labour was more highly developed and complex than peasant labour. ${ }^{82}$ Labour processes in the canefields expressed a more socialized and historically more developed organization that co-ordinated and integrated the labour of the piñoneros and

Rico government (and, indirectly, of at least segments of the US government), and against the wishes of many or most cane employers.

${ }^{76}$ Significantly, task-work was also the norm in Piñones peasant labour such as wood. cutting, while piece-work governed coconut husking.

$\pi$ Task-work remains especially important in the construction industry, especially in smaller projects.

${ }_{73}$ The question of task-work raises many issues that extend deep into plantation slavery. See Tomich, Slavery in the Circuit of Sugar, pp. 245-248; Philip Morgan, "Work and Culture: The Task System and the World of Low Country Blacks, 1700-1880", William \& Mary Quarterly, XXXIX (1982), pp. 563-599; idem, "Task and Gang Systems: The Organization of Labor on New World Plantations", in Stephen Inness (ed.), Work and Labour in Early America (Chapel Hill, 1988), pp. 157-219.

${ }^{n}$ On the labour gangs of freedmen shortly after emancipation, sec Andrés Ramos Mattei, "El liberto en el régimen de trabajo azucarero en Puerto Rico, 1870-1880", in Ramos Mattei (ed.), Azuicar y esclavitud (Río Piedras, 1982).

"Mintz, "Cañamelar", p. 349.

${ }^{81}$ Ibid.

of course, this has large political implications; see Raymond Williams, The Country and the City (New York, 1973). 
other loiceños in field and factory, to a degree unthinkable in peasant labour. . $^{83}$

Thus my final point with respect to the peasant dimensions of canefield labour concerns simple co-operation: the integrated, co-operative, and often largely manual labour processes conceptualized by Marx in Capital. This angle has been largely overlooked by students of sugar canefield labour, or of rural labour generally. ${ }^{24}$ Co-ordination between cane cutting, carrying and loading made for an astonishing development of simple co-operation in the canefields. The urgency of deploying vast amounts of labour at a given time is part and parcel of the relationship between "production time" and "labour time" in sugar cane agriculture. ${ }^{85}$

Marx valued the complexity and productive power of rural simple cooperation more than most of his students have noticed ${ }^{86}$ His comments on "rural idiocy" and peasants as "potatoes" in more journalistic texts have overshadowed his perspectives on simple co-operation in agriculture. Marx criticized Aristotle's assumption that sociability was necessarily urban, and proposed a rural polis of simple co-operation. Co-operation multiplied the energies of the workers by begetting "a rivalry and a stimulation of the 'animal spirits'". ${ }^{87}$ And remarkably, Marx even writes that co-operation (not the expropriation of smallholders?!) was "the starting-point [that] coincides with the birth of capital". ${ }^{88} \mathrm{He}$ envisaged as a pre-eminent terrain for simple co-operation "that kind of large-scale agriculture which corresponds to the period of manufactures", where substantial numbers of workers laboured in integrated labour processes, with or without tools. ${ }^{89}$

Simple co-operation has always been, and continues to be, the predominant form in those branches of production in which capital operates on a large scale, but the division of labour and machinery plays only an insignificant part. ${ }^{90}$

w "Less than thirty-five hours from standing cane to sugar in the sack is the aim at Central Canovanas. Within twenty-four hours from the swing of the machete in the field, the cane is delivered to the unloader at the mill. In eight to ten hours from the time the cane reaches the revolving knives, sugar pours into the bag". Uttley, "Land Utilization in the Canovanas Sugar District", p. 155.

* But see David H. Morgan, "The Place of Harvesters in Nineteenth-century Village Life", in Raphael Samuel, Village Life and Labour (London, 1975), pp. 27-72, and others in that collection; idem, Harvesters and Harvesting: $A$ Study of the Rural Proletariat (London, 1982).

is Thus there are "critical moments [ . . ] determined by the nature of the labour process, during which certain definite results must be obtained": Karl Marx, Capital, I (New York, 1976), p. 445. In a "combined working day", shortness of time is compensated for by the large mass of labour thrown into the field of production at the decisive moment: ibid.

6 Ibid., ch. 13.

Ibid., p. 443. This was already present in the second form of co-operation, as Marx stressed.

"Ibid., p. 453. This viewpoint meshed with Marx's "heroic" sense of the rural proletariat as a world-historical class, and clashed with the historical account that Marx offers of the "gypsy" labour gangs in England. But then that "tension" runs throughout Marx's writings on the rural proletariat. Giusti-Cordero, "Labour, Ecology and History", ch. 2.

* Marx, "Capital, I, p. 444.

90 Ibid., p. 454. See also pp. 441-442 on two other forms of co-operation. 
Sugar plantation field labour in the Caribbean certainly fits this description. Sugar labour, indeed, is an excellent example of how simple co-operation involves peasant and proletarian dimensions. The complex peasant-proletarian patterns of Puerto Rico's canefields probably obtained through the collapse of large-scale sugar production in the 1960s. True, the generalization of time-wages at the beginning of that decade appears to mark the arrival of a rural proletariat in Puerto Rico's canefields. Yet in Piñones as elsewhere, if anything, there may have been a process of deproletarianization after 1940: (1) technological advances expanded "dead time", at a quickening pace;" (2) the colonial state expropriated tens of thousands of acres of corporate sugar cane lands, and a new state sugar corporation became the largest employer of sugar cane field labourers; (3) a fraction of the land expropriated by the Authority was distributed in allotments (parcelas) to landless labourers; (4) Puerto Rico's sugar production contracted as the US federal tariff system opened its doors more widely to foreign sugars, and US and world sugar prices declined; and (5) very significantly, a massive emigration gushed to Puerto Rican cities and to the US. ${ }^{92}$

Rural proletarianization, in so far as it came about in Puerto Rico after 1940, may have been less a sign of the maturity of the "American Sugar Kingdom" in the hispanophone Caribbean, as is suggested in Mintz and others, than a sign of impending demise and transformation.

\section{Tropical discourse}

In recent decades, the question of the social and historical character of large-scale plantation wage labour has been relatively neglected by world social science, particularly with respect to sugar-central production. This may be due to the brilliant ethnography of Sidney Mintz's original research, as well as its congenial mix of Marxist and Weberian approaches. ${ }^{93}$

91 Already in the 1930s, Gayer and associates found that there was a "trend toward successively greater drops in employment during the slack months, particularly in field labour": Gayer et al., The Sugar Economy of Puerto Rico, p. 180; Puerto Rico Minimum Wage Board, La industria de azúcar, pp. 76, 180; see also Mintz, Worker in the Cane, p. 272.

92 Ibid., p. 273. Total migration from Puerto Rico to the US shot up from 151,000 in 1940-1949 to 430,000 in 1950-1959, the greatest increase ever both in absolute and relative amounts. José L. Vázquez Calzada, La población de Puerto Rico y su trayectoria historica (Rio Piedras, 1978), p. 277.

${ }^{93}$ In the field of agrarian history, and particularly regarding agrarian capitalism, Marx and Weber are in any case quite close. In his study of East Elbian agriculture, Weber considers "the transformation from the estate economy into a capitalistic economy on the basis of the underlying organization of labor": Martin Riesebrodt, "From Patriarchalism to Capitalism: The Theoretical Context of Max Weber's Agrarian Studies (1892-3)", in Kenneth Tribe (ed.), Reading Weber (London, 1989), p. 140. Riesebrodt adds: "In his analysis of the proletarianization process [Weber] also underlines the same elements as Marx": ibid. 
In Puerto Rico, the authority of Mintz's perspective on Puerto Rican social history has been especially strong. Mintz and The People of Puerto Rico as a whole "have exerted decisive influences in the historical literature [of Puerto Rico] of recent years";"4 Mintz's work has been the source of "many of our ideas on the trajectory of sugar in our milieu".95 "Cañamelar" and Mintz's related writings were pillars of "capital importance" of the "New History" (la Nueva Historia). ${ }^{96}$ Interest in Puerto Rico paralleled attention to The People of Puerto Rico, and particularly in the work of Mintz and Wolf, on the part of AngloAmerican "dependency studies" and then "peasant studies".

In the early 1970s, Angel Quintero Rivera's work on the Puerto Rican rural proletariat followed the main lines of Mintz's argument, and it was through Quintero's work that Mintz's influence has been especially strong in Puerto Rico. ${ }^{97}$ Quintero Rivera laid a cornerstone of the "New History" with his analysis of the sugar cane rural proletariat (proletariado cañero). ${ }^{98}$ While differences exist between the two authors - for instance, Quintero Rivera stressed broad political and ideological dimensions there are also strong continuities. In both Mintz and Quintero, capitalist social relations governed after 1898 (though Mintz posited a longer "transition"); and historical agency pertained basically to the US sugar corporations. Little is said of autochthonous agrarian social relations and their problematic mesh with the new order of things. Mintz and Quintero Rivera stripped the bourgeoisie and the rural working class of their complexity; the many "peasant" dimensions of the sugar labourers, and indeed the "proletarian" dimensions of their peasant patterns, were

24 Scarano, "Las huellas esquivas de la memoria", p. 37.

9s Scarano, "El colonato azucarero en Puerto Rico, 1873-1934: problemas para su estudio", Historia y Sociedad, III (1990), p. 155.

96 Scarano, "Las huellas esquivas de la memoria", p. 13. Gordon Lewis's masterly Puerto Rico: Freedom and Power in the Caribbean (New York, 1963) further strengthened the authority of Mintz's analysis in Puerto Rico. Lewis argued that in the twentieth century Puerto Rican rural workers became propertyless and wage-earning workers "in the classical sense", especially in the island's "locus classicus of economic change", the sugar industry: Freedom and Power, pp. 89, 95.

"7 For example, Quintero Rivera, "El capitalismo y el proletariado rural", Revista de Ciencias Sociales, XIX (1974), pp. 61-103; Quintero Rivera and Garcia, Breve historia.

98 On several important issues, Quintero Rivera pushed Mintz's already bold conclusions even further. Three "new historians" offered dissenting voices: Gervasio Garcfa called attention to the strong "precapitalist" features of the Puerto Rican rural labour force, and political economy as a whole, into the twentieth century; the argument around "irregular labour discipline", discussed above, is part of that analysis: Garcia, "Economia y trabajo". Andrés Ramos Mattei stressed the significance of sugar-central production prior to 1898, and thus raised vital questions about the real meanings of US penetration: Ramos Mattei, La sociedad del azuicar en Puerto Rico: 1870-1910 (San Juan, 1988). And Fernando Pico has demonstrated the resilience of smallholders and the durability of black circum-cane labourer communities: Amargo cafe: los pequñeos y mediados caficultores de Utuado a fines del siglo XIX (Rio Piedras/Huracán, 1979); idem, Vivir en Caimito (Rfo Piedras, 1979). 
almost deliberately obscured (as were the mercantile and financial dimensions of the agrarian bourgeoisie). ${ }^{99}$

In Mintz's and Quintero's reading, the US sugar centrals became "the bourgeoisie" and the sugar workers (representing the rest of the nation) became the "proletariat". Despite its radical and class strains, such a perspective happens to mesh easily with old currents of hispanophone Caribbean nationalism; in a sense, both Quintero Rivera and Mintz are heirs of Fernando Ortiz and Ramiro Guerra y Sánchez. ${ }^{100}$ Thus native social classes come into view only as victims of massive US capital although Mintz and Quintero make rural proletarians, rather than the colonos and guajiros (analogous to jibaros), the heroic victims. ${ }^{101}$

Especially in Quintero's account, proletarians (rural, invariably led by urban artisans-cum-proletarians) are made to be the bearers of the nation. Thus Quintero Rivera collapsed the national question into working-class politics: the rise of the rural proletariat was, to Quintero Rivera and to many of the "New Historians", the strongest evidence that cultural-nationalist interpretations of Puerto Rican history and the symbology of the jibaro missed the acute class conflicts of early twentiethcentury Puerto Rico.

Quintero Rivera held in tension the national and class dimensions of his analysis. Subsequent work basically forked off in one or another direction: towards a narrow class reading (José Luis González), perhaps close to Mintz, or towards a narrow nationalist interpretation (Taller de Formación Política, a research collective). In País de cuatro pisos, ${ }^{102}$ González invoked Quintero's research to dismiss Puerto Rican nationalist politics in the 1930s as Fascist, and situated the peasant jibaro as a banner of that current. Gonzalez located the nation rather in the black and mulatto coastal population, presumably with special force among rural proletarians. The Taller exalted nationalism and especially Pedro Albizu Campos, claiming that he converged with the sugar workers once again viewed as "classic" rural proletarians - in the 1930s. Both "forks" after Quintero are a departure from hispanophone Caribbean nationalism, but neither goes beyond being mirror reversals-in-continuity of it.

The question of the rural proletariat is evidently entwined with the controversy between national vs. class politics in Puerto Rico. However, subsequent discussion turned on a putative Puerto Rican "national bourgeoisie", while the agricultural proletariat remained a murky presence assumed, and at times asserted, but never subjected to critical scrutiny.

\footnotetext{
99 See Giusti-Cordero, "En búsqueda de la nación concreta"; idem, "Hacia otro 98: el 'grupo español' en Puerto Rico".

${ }_{100}$ Fernando Ortiz, Cuban Counterpoint (New York, 1947); see Mintz, "Foreword" to Guerra y Sanchez, Sugar and Society in the Caribbean.

101 Martínez Alier, Cuba: economía y sociedad.

100 Jose Luis González, El pals de cuatro pisos (Río Piedras, 1980).
} 
Indeed, the most prominent themes in recent years have moved even further away from agrarian social relations: the social and political character of the Puerto Rican nationalism, the hispanismo of the intellectual elite, the ideology of its riveting leader Albizu Campos. ${ }^{103}$ In the background of these debates lay more practical and messy issues concerning the direction ("workerist" vs. more national) and political alliances of the complex Puerto Rican independence-socialist movement in the 1970s-1980s, which happened to be the matrix of most "new historians".

The counterpoint in Puerto Rico between the categories of peasant and rural proletariat, as typically defined, is suggestive. To a large extent, this dichotomy has defined discussions of Puerto Rican cultural and social history, and national identity, over most of this century. In Puerto Rico, as elsewhere, anthropological argument has been the stuff of cultural discussion and political folklore. But the opposite is also true, perhaps rarely with such force as in Puerto Rico, for The People of Puerto Rico project canonized both the categories of rural proletarian and peasant in world anthropology as part and parcel of its detonation of Puerto Rican national identity. People researcher Robert Manners was perhaps especially forthright: in his analysis, he stated, Puerto Rico

has been seen in reality as a number of interrelated subcultures with certain basic similarities running throughout, but with many differences owing not only to the pattern of earning a living but the way in which each person is related to the means of earning a living. On the basis of this investigation, we have been forced [!] to reject any assumption that the cultural particulars found among the people in any one region - especially the particulars involved directly and indirectly in the relationship of people to the land - will be just like those found in other regions of the island. We see even less reason for any assumptions of a homogeneous national character for the people of Puerto Rico. ${ }^{104}$

Thus Puerto Rico's vernacular discussions of class and nation in the 1920s-1940s acquired unusually broad, if often implicit, ramifications, while subsequent Puerto Rican discussions were significantly shaped by the vast and authoritative field of world anthropology and social science.

The peasant-rural proletarian dichotomy at the heart of the Steward project was at least partially a political project of the PPD and allied metropolitan interests. For the PPD privileged the jibaro peasant with

${ }^{103}$ Quintero Rivera, "Historia de unas clases sin historia. Comentarios criticos al Pats de cuatro pisos" (San Juan, 1983); Taller de Formación Política, La cuestión nacional; Luis Angel Ferrao, "Nacionalismo, elite intelectual e hispanismo en el Puerto Rico de los años treinta", in Silvia Alvarez-Curbelo and Maria Elena Rodríguez Castro (eds), Del nacionalismo al populismo: cultura y polftica en Puerto Rico (Rio Piedras, 1993), pp. 37-60; Luis Ferrao, Pedro Albizu Campos y el nacionalismo puertorriqueño (Rio Piedras, 1990); Taller de Formación Política, Pedro Albizu Campos: conservador, fascista o revolucionario (Rio Pjedras, 1991); Juan Manuel Carrión et al., La nación puertorriqueria: ensayos en torno a Pedro Albizu Campos (Rlo Piedras, 1993).

304 Manners, "Tabara", pp. 168-169 (emphasis added). 
its left hand even as with its right hand it split both the CGT (Confederación General de Trabajadores), energized by newly powerful sugar worker unions in 1945, and the independence movement. The CGT was aligned with the CIO in the US and had a sizeable Communist and pro-independence presence. Mintz disingenuously attributed the division of the CGT unions to "internal dissension", and found an "identity of interests" between the PPD and the (now deeply PPD-manipulated) CGT into the 1948 elections, ${ }^{105}$ a moment of decisive political conflict in Puerto Rico. The torpedoing of the Congreso pro Independencia (by both the PPD and the US government) receives a similarly cavalier treatment in People, which describes pro-independence forces as being in the main "bitterly anti-American". ${ }^{106}$

The jibaro privileged by the PPD, which was indeed a specific version of the jibaro, informed the reading made by The People of Puerto Rico of Puerto Rico's rural population. The PPD jibaro resonates in People both affirmatively - as in Wolf's research - and negatively in Mintz's account of the rural proletariat. Both Wolf and Mintz constructed (and "saw") the rural proletariat largely in contrast to the jibaro peasant, and both underpinned (and "naturalized") the jibaro/rural proletarian social dichotomy with a further, spatial dichotomy between highland and lowland.

And both Wolf and Mintz not incidentally affirmed the class rather than class and national content of Puerto Rico's decisive political conflicts of the 1940s. In the broader context of the Steward project, Mintz and Wolf generated an ideological, colonialist interpretation of Puerto Rican history that neither of these important anthropologists has ever reassessed.

Later, in the "New History", the rural proletariat and the jibaro ${ }^{107}$ were again held in tension as dichotomy. Perhaps trapped by the dichotomy, Quintero attempted a strategy that was almost doomed from the start: to instil the class construct of the rural proletariat with a national content. ${ }^{108}$ Quintero's attempt remained unpersuasive: his writings on the working-class patria find only urban artisan-intellectuals; and, on the whole, these were linked to sugar workers tenuously at best.

I have argued here that we need to go beyond dichotomies or counterpoints between peasants and rural proletarians. ${ }^{109}$ The relationship was

${ }^{105}$ Mintz, "Cañamelar", p. 397. For a contrasting interpretation of the CGT split, see Quintero Rivera and García, Desafio y solidaridad, pp. 124-125.

tos Ibid., p. 82; but see Francisco Scarano, Puerto Rico: cinco siglos de historia (San Juan, 1993), pp. 722-726.

${ }^{107}$ Perhaps not trivially, the term "rural proletariat" is usually phrased as plural, while "jibaro" appears as the singular.

108 Quintero Rivera, "Puerto Rican National Development: Class \& Nation in a Colonial Context", Marxist Perspectives, IX (1980), pp. 10-31.

${ }^{109}$ For a pathbreaking analysis of the "peasant" and "proletarian" dimensions of slave labour, see Tomich, Slavery in the Circuit of Sugar, pp. 261-262. Tomich qualifies Mintz's concept of "proto-peasant" not by arguing, as some have done, for the formation of an 
rather one between peasant and proletarian dimensions pervading both the nominally "peasant" and "rural proletarian" milieux. In other words, the "factory in the field" of classic description in Mintz's "Cañamelar" was indeed a factory in the field: the sugar mill. Yet that hardly exhausted the characterization of the "field". And in this perspective, another metaphor that Mintz employed, the "land-and-factory combine", becomes a land-and-factory and village combine, or perhaps more concretely a land-and-factory-and labour combine, with "labour" itself having quite complex meanings. ${ }^{110}$

Culturally and otherwise, universal rural proletarianization and wholesale destruction of peasant subsistence - assuming that swift suppression of peasant practices and outlooks is possible - was not necessarily in the interest even of the sugar centrals corporations, or for that matter any other capitalist enterprise. Under full proletarianization, the reproduction costs of the labourer would fall below that of the wages, or the labourer would reproduce his or her labour only partially. Productivity would plummet amidst disease, in the end imperilling the existence of the labourer population itself. On the other hand, the very skills that plantation labour required are in many ways peasant skills, honed at least partly in peasant milieux.

In Piñones, an old black lowland population of "squatter"/peasantwoodsmen-fishermen communities entered the sugar-central era with a strong, and already complex, heterogeneous "peasant" background, notwithstanding the physical proximity of the mills. The pre-plantation history of a labourer population needs to be weighed seriously, especially where the labourer populations predate large-scale plantation development in a particular region - as was the case in the hispanophone Caribbean.

In the Piñones villages, an array of labour patterns defined the piñoneros as peasants, and far more than that: they farmed cropland, but also grazed cattle, fished and caught crabs, cut wood and made charcoal, extracted madera negra, felled and shelled coconuts, etc., in a variety of arrangements some of which were laced with proletarian dimensions.

Proletarian labour processes such as cutting and loading were intertwined in the canefields with more "peasant" processes such as planting and fertilizing. Following the ambiguous rhythms of natural and sociallydeveloped seasons, and of seasons within seasons, the Piñones labourers moved actively between forms of peasant labour, peasant and proletarian spaces, and undertook work in the canefields much as they did within

independent peasantry, but "by examining the historical interrelation between the various types of laboring activities performed by the slave population". At the same time, Tomich locates the "focal point" of the development of the slaves" autonomous production and marketing activities in "the struggle between master and slave over the conditions of labor and of social and material life within slavery": ibid., p. 261.

${ }^{110}$ See Warman, "El problema del proletariado agricola". 
labour processes. This takes us beyond received images of a uniformly proletarianized lowland black population.

Upon the onset of sugar-central production in the early twentieth century, the labourers of Piñones, like many of Puerto Rico's field labourers generally, did not become merely landless, waged rural proletarians devoted overwhelmingly to sugar cane labour. Peasant activities may have been "subsidiary" in terms of cash income, but not so in terms of their importance for subsistence, or for the social autonomy of the labourers.

Mintz ultimately recognized as much in "Cañamelar", in a crucial passage near the end of the study whose full meaning we may now appreciate and which anticipated Mintz's more historical sense of the peasant-plantation relationship in later work. Mintz had elsewhere recognized the existence of non-cane activities among rural proletarians of "Cañamelar", but relegated them to "subsidiary economic activities". Now, in reference to persistent "folk arts and skills" - or is it "peasant arts and skills"? - those activities appear as far more than "subsidiary".

One of the remarkable features of the life of the rural proletariat is its curious blending of the patterns we think of as customarily urban, such as landlessness, wage-earning, food-buying, etc., with those associated with rural life. The values of folk arts and skills come to have special meaning in such a context, particularly since life is as dependent in many ways on successful subsidiary economic activities as it is on the main wage-earning activity (Mintz offers examples). These random examples demonstrate that the rural proletarian subculture has not been stripped bare of its earlier material culture and technology by the imposition of the land-and-factory combine system. In many areas of life, new material items - including foods, fabrics, containers and shoes - have partly supplanted more traditional ones which were home-made rather than purchased. But the innumerable items of culture which make life possible, which help to shape it and to give it depth and meaning, have by no means been completely eradicated. Life in Barrio Poyal is not urban life nor is it nural: it consists of a mixture of the features of both urban and rural in special ways and in a special historical setting. ${ }^{112}$

If rural proletarians combined, according to these strategic comments, rural and urban material life, might not they also combine peasant and proletarian, as a "mixture of the features of both [ . . . ] in special ways and in a special historical setting"? ${ }^{113}$ Mintz almost palpably drew back from the implications of his findings. Even the terms "rural proletarian" and "peasant" do not appear in a straightforward manner in this com-

111 Of course, the cultural significance of those activities was a concern that Mintz the anthropologist could not elude and which in any case could not be measured only quantitatively.

112 Mintz, "Cañamelar", p. 401; emphasis added.

113 Ibid; emphasis added. 
mentary: peasant is coded as "folk" and as "the earlier material culture and technology", while "rural proletarian" appears as the "urban".

We need to move beyond perspectives on Puerto Rico, as elsewhere, that render social history in fragmented ways and tend to promote undemocratic political objectives. Such is the case of the dichotomous concepts of "peasant" and "rural proletariat", which had their origins in anthropological research in Puerto Rico. Exploring concepts brings us closer to social reality, if our concepts become as fluid as the reality that they (we) explore. 